\title{
PENGARUH JENIS DAN DOSIS PUPUK ORGANIK TERHADAP PERTUMBUHAN DAN HASIL TANAMAN TERONG (Solanum melongena L.) VARIETAS MILANO
}

\author{
Muhammad Fadil ${ }^{1}$, dan Hery Sutejo ${ }^{2}$ \\ ${ }^{1}$ Agroteknologi, Fakultas Pertanian, Universitas 17 Agustus 1945 Samarinda, Indonesia. \\ ${ }^{2}$ Dosen Fakultas Pertanian, Universitas 17 Agustus 1945 Samarinda 75124, Indonesia. \\ E-Mail: yani8074@yahoo.com
}

\begin{abstract}
ABSTRAK
Pengaruh Jenis dan Dosis Pupuk Organik Terhadap Pertumbuhan dan Hasil Tanaman Terung (Solanum melongena L.) Varietas Milano. Tujuan penelitian untuk mengetahui pengaruh jenis dan dosis pupuk organik serta interaksinya terhadap pertumbuhan dan hasil tanaman terong, serta untuk mengetahui jenis dan dosis pupuk organik yang tepat untuk menghasilkan tanaman terung yang tinggi.

Penelitian dilaksanakan selama \pm 4 bulan, yaitu mulai akhir bulan Februari 2017 sampai dengan bulan Mei 2017, di Kecamatan Sangatta Utara, Kabupaten Kutai Timur, Kalimantan Timur. Penelitian menggunakan Rancangan Acak Lengkap (RAL), dalam percobaan faktorial $3 \times 3$, dengan 4 ulangan. Terdiri atas 2 faktor perlakuan. Faktor I adalah jenis pupuk organik $(\mathrm{K})$, terdiri atas 3 taraf, yaitu : pupuk kompos $\left(\mathrm{k}_{1}\right)$, pupuk kandang sapi $\left(\mathrm{k}_{2}\right)$, dan pupuk kandang ayam $\left(\mathrm{k}_{3}\right)$. Faktor II adalah dosis pupuk organik (D), terdiri atas 3 taraf, yaitu : dosis pupuk 5 ton/ha setara $50 \mathrm{~g} / \operatorname{tanaman}\left(\mathrm{d}_{1}\right)$, dosis pupuk 10 ton/ha setara $100 \mathrm{~g} / \operatorname{tanaman}\left(\mathrm{d}_{2}\right)$, dan dosis pupuk 15 ton/ha setara $150 \mathrm{~g} / \operatorname{tanaman}\left(\mathrm{d}_{3}\right)$.

Hasil penelitian menunjukkan bahwa perlakuan jenis pupuk organik (K) tidak berpengaruh nyata terhadap tinggi tanaman umur 15 dan 30 hari setelah tanam, dan umur saat berbunga. Berpengaruh nyata terhadap tinggi tanaman umur 45 hari setelah tanam, Berpengaruh sangat nyata terhadap jumlah buah per tanaman dan berat buah per tanaman. Berat buah terung tertinggi terdapat pada perlakuan $\mathrm{k}_{3}$ (pupuk kandang ayam), yaitu $1,62 \mathrm{~kg} /$ tanaman, sedangkan yang terendah terdapat pada perlakuan $\mathrm{k}_{1}$ (pupuk kompos), yaitu 1,14 $\mathrm{kg} / \mathrm{tanaman}$.
\end{abstract}

Kata kunci : Pertumbuhan, Pupuk organik, Tanaman terong.

\begin{abstract}
Effect of Type and Dosage of Organic Fertilizers on Growth and Yield of Egg plant (Solanum melongena L.) Milano variety. The aim of research was to study the effect of type and dosage of organic fertilizers and their interaction on the growth and yield of eggplant, as well as to determine the proper type and dosage of organic fertilizers which produced the highest crop egg plant.

The research was conducted for aboutfour months, starting in late February 2017 to Mey 2017, at the sub district of North Sangatta, East Kutai Regency, East Kalimantan. It employed a Completely Randomized Design (CRD), in $3 \times 3$ factorial experiment, with four replications. The research consisted two factors. The first factor was the type of organic fertilizer $(K)$, consists of three levels, namely: compost $\left(k_{1}\right)$, cow manure $\left(k_{2}\right)$, and chicken manure $\left(k_{3}\right)$. The second factor was the dosage of organic fertilizer $(D)$, consisted of three levels, namely: 5 ton/ha equivalent to $50 \mathrm{~g} /$ plant $\left(d_{1}\right), 10$ tons/ha equivalent to $100 \mathrm{~g} / \mathrm{plant}\left(d_{2}\right)$, and $15 \mathrm{ton} / \mathrm{ha}$ equivalent to $150 \mathrm{~g} /$ plant $\left(d_{3}\right)$.

The research results showed that the treatment of organic fertilizer type do not affect significantly on the plant height at 15 and 30 days after planting, and the age at flowering. It affected significantly on the plant height at 45 days after planting. It affected very significantly on the number of fruits per plant and the weight of fruit per plant. The heaviest eggplant fruit weight was attained at the $k_{3}$ treatment, with 1,62 $\mathrm{kg} / \mathrm{plant}$, while the lightest one was attained at the $k_{1}$ treatment, with $1.14 \mathrm{~kg} / \mathrm{plant}$.
\end{abstract}

Key words : Growth, Organic Fertilizers, Yield of Egg plant. 


\section{PENDAHULUAN}

Tanaman terong (Solanum melongena L.) merupakan salah satu golongan sayuran yang banyak digemari berbagai kalangan karena rasanya yang enak juga mengandung gizi cukup tinggi dan komposisinya lengkap. Kandungan gizi terung mencakup kalori, protein, lemak, karbohidrat, serat, abu, kalsium, fosfor, zat besi, natrium, kalium, vitamin $A$, vitamin $B_{1}$, vitamin $B_{2}$, vitamin $C$, niacin, dan air (Rukmana, 1994), sehingga baik untuk kesehatan tubuh manusia.

Selain bernilai gizi yang tinggi, tanaman terungjuga memiliki nilai ekonomis dan sosial yang cukup tinggi. Hasil produksi terung tidak hanya laku dipasaran dalam negeri(domestik) tetapi juga sudah menjadi mata dagang ekspor. Bentuk produk terung yang sudah menembus pasar ekspor adalah terung asinan(Rukmana,1994). Distribusi pemasarannya tidak hanya dilakukan dipasar-pasar tradisional saja, namun juga disupermarket ataupun toko-toko swalayan. Oleh sebab itu, komoditas terung sangat potensial untuk dikembangkan secara intensif.

Di Kalimantan Timur,produksi terung pada tahun 2014 mencapai 14.880 ton. Kecenderungan pada tahun 2010 2012 mengalami penurunan produksinya, sedangkan pada tahun 2013 - 2014 mengalami peningkatan. Sementara itu hasil terung pada umumnya terjual baik di pasar lokal. Dengan demikian masih terdapat potensi yang menguntungkan untuk meningkatkan produksi terung di daerah ini (Biro Pusat Statistik, 2015).

$$
\text { Untuk meningkatkan }
$$

produktivitas tanaman diantaranya adalah melalui upaya pemberian pupuk. Pemupukan yang dilakukan bertujuan untuk memenuhi kebutuhan tanaman akan unsur hara yang dibutuhkan selama pertumbuhannya.

$$
\text { Kesuburan tanah didalam }
$$

pertanian adalah status tanah yang menunjukan kapasitas untuk memasok unsur-unsur esensial dalam jumlah yang mencukupi untuk pertumbuhan tanaman. Kesuburan tanah dapat berubah, menurun atau meningkat,dapat terjadi secara alami atau perbuatan manusia, dapat berupa kurangnya konsentrasi unsur hara yang tersedia,kandungan bahan organik, kapasitas tukar kation, dan perubahan $\mathrm{pH}$ yang disebut sebagai penurunan kesuburan kimiawi (Musnamar, 2009).

Banyak upaya telah dilakukan untuk menambah unsur hara pada tanaman,baik melalui bagian tanaman (daun) maupun tanah. Pertumbuhan tanaman yang baik dan produktivitas yang tinggi dapat dicapai, selain dengan memperhatikan syarat-syarat pertumbuhannya juga memerlukan pemeliharaan yang baik pula. Salah satunya adalah melalui pemupukan, berupa pemberian berbagai jenis pupuk organik maupun.

Pemupukan dalam pemeliharaan tanaman sangat diperlukan untuk meningkatkan ketersediaan unsur hara di dalam tanah, yang pada akhirnya untuk meningkatkan produksi tanaman. Salah satu jenis pupuk yang belakangan ini banyak digemari oleh petani adalah pupuk organik.

Penggunaan pupuk organik sangat dianjurkan karena memiliki dampak ramah lingkungan terhadap pencemaran lahan pertanian. Pupuk organik mampu meningkatkan kandungan unsur hara dalam tanah, juga memberikan pengaruh yang baik terhadap sifat fisik dan kimia tanah, sehingga tanah menjadi subur.

Berdasarkan hal tersebut diatas, maka dilakukan penelitian mengenai "Pengaruh Jenis dan Dosis Pupuk OrganikTerhadap Pertumbuhan dan Hasil Tanaman Terong (Solanum melongena L.) Tujuan Penelitian adalah untuk mengetahui pengaruh jenis dan dosis pupuk organik serta interaksinya terhadap 
pertumbuhan dan hasil tanaman terong.

Untuk mengetahui jenis dan dosis pupuk organik yang tepat untuk menghasilkan tanaman terong yang tinggi.

\section{METODA PENELITIAN}

\subsection{Tempat dan Waktu}

Penelitian dilaksanakan di Kecamatan Sangatta Utara, Kabupaten Kutai Timur, Kalimantan Timur. Pada bulan Februari-Mei 2017.

\subsection{Bahan dan Alat}

Bahan yang digunakan yaitu: pupuk kompos, pupuk kandang sapi dan pupuk kandang ayam, benih terung hijau varietas Milano, Furadan $3 \mathrm{G}$, Dithane M-45, polibag ukuran $40 \mathrm{~cm}$ $\mathrm{x} 40 \mathrm{~cm}$. Sedangkan alat yang digunakan adalah: parang, cangkul, ember, gembor, hand spayer, meteran, alattulis-menulis, laptop, kalkulator, timbangan analitik dan kamera untuk dokumentasi penelitian.

\subsection{Rancangan Percobaan}

Penelitian ini menggunakan

Rancangan Acak Lengkap (RAL), dalam percobaan faktorial $3 \times 3$, dengan 4 ulangan. Terdiri atas 2 faktor perlakuan, yaitu sebagai berikut :

Jenis Pupuk Organik (K), terdiri atas 3 taraf, yaitu :

$$
\begin{array}{ll}
\mathrm{k}_{1}= & \text { pupuk kompos } \\
\mathrm{k}_{2}= & \text { pupuk kandang sapi } \\
\mathrm{k}_{3}= & \text { pupuk kandang ayam }
\end{array}
$$

Dosis Pupuk Organik (D) terdiri atas 3 taraf, yaitu :

$$
\begin{array}{ll}
\mathrm{d}_{1}= & \begin{array}{l}
\text { dosis pupuk } 5 \text { ton } / \mathrm{ha}, \\
\text { setara } 50 \mathrm{~g} / \mathrm{tanaman}
\end{array} \\
\mathrm{d}_{2}=\quad \begin{array}{l}
\text { dosis pupuk } 10 \mathrm{ton} / \mathrm{h}, \mathrm{a} \\
\text { setara } 100 \mathrm{~g} / \mathrm{tanaman}
\end{array}
\end{array}
$$

$$
\begin{aligned}
& \mathrm{d}_{3}=\quad \text { dosis pupuk } 15 \text { ton } / \mathrm{ha}, \\
& \text { setara } 150 \mathrm{~g} / \operatorname{tanaman}
\end{aligned}
$$

Terdapat kombinasi perlakuan $3 \times 3$

$=12$, sebagai berikut :

$\begin{array}{lll}\mathrm{k}_{1} \mathrm{~d}_{1} & \mathrm{k}_{1} \mathrm{~d}_{2} & \mathrm{k}_{1} \mathrm{~d}_{3} \\ \mathrm{k}_{2} \mathrm{~d}_{1} & \mathrm{k}_{2} \mathrm{~d}_{2} & \mathrm{k}_{2} \mathrm{~d}_{3} \\ \mathrm{k}_{3} \mathrm{~d}_{1} & \mathrm{k}_{3} \mathrm{~d}_{2} & \mathrm{k}_{3} \mathrm{~d}_{3}\end{array}$

\subsection{Peosedur Penelitian}

Penyemaian Benih

Benih tanaman terung yang akandisemaimerupakan benih yang berasal dari benih hibrida (benih yang bermutu).Benih terong disemai pada petak atau bedeng semai yang telah disiapkan, dan terbuat dari kayu dengan ukuran $1 \mathrm{~m}$ x $1 \mathrm{~m}$. Media dipersemaian merupakan campuran tanah top soil dan pupuk kandang sapi dengan perbandingan $1: 1$. Bila bibit terong dipersemaian telah berdaun 3 atau 4 helai, maka segera dipindah ke media tanam di polibag yang telah disiapkan sebelumnya.

\section{Persiapan Media Tanam}

a. Pembuatan media tanam

Tanah yang dijadikan media tanam adalah tanah topsoil, yang diambil disekitar tempat penelitian. Tanah dicampur jadi satu, dicampur secara merata, kemudian dipisahkan dari kotoran seperti rumput, akar, kayu dan lainnya dengan tujuan untuk memperoleh tanah yang seragam dan bebas dari kotoran lainnya. Tanah yang telah dicampur tersebut kemudian ditambahkan Furadan $3 \mathrm{G}$ dan dibiarkan selama 3 hari.

b. Pengisian tanah di polibag

Tanah top soil yang telah dicampur dangan Furadan $3 \mathrm{G}$ tersebut kemudian dimasukan kedalam polibag dangan ukuran $40 \mathrm{~cm}$ x 40 cmdengan berat tanah $\pm 20 \mathrm{~kg}$. Jumlah polibag yang dipersiapkan untuk diisi media tanam berjumlah 38 polibag. Kemudian polibag 
disusun dilokasi penelitian sesuai dengan tata letak yang telah di acak menggunakan cara undian.

\section{Pemindahan Bibit di Polibag}

Setealah bibit terong berdaun 3 helai (umur 2 minggu setelah persemaian), dilakukan pemindahan bibit dengan cara membuat lubang tanam pada media tanam dalam polibag. Tiap polibag ditanam 1 (satu) bibit yang sehat dan seragam (tinggi dan jumlah daun).

\section{Pemberian Pupuk Organik}

Pupuk organik diberikan 1 minggu sebelum tanam, dengan caradibenamkan dan dicampur dengan tanah (media tanam) secara merata. Pupuk organik yang diberikansesuai perlakuan, yaitu: pupuk kompos, pupuk kandang sapi dan pupuk kandang ayam, masing-masing sesuai dosis perlakuan, yaitu: dosis pupuk 5 ton/ha (50 g/tanaman), 10 ton/ha (setara 100 g/tanaman), dan 15 ton/ha (150 g/tanaman).

\section{Pemeliharaan}

a. Penyiraman

Penyiraman dilakukan apabila hari tidak hujan, dan dilakukan pada pagi dan sore hari, penyiraman dilakukan secukupnya saja, apabila tanah cukup lembab maka tanaman tidak perlu disiram.

\section{b. Penyulaman}

Penyulaman dilakukan apabila ada benih yang tidak tumbuh atau bibit yang mati. Penyulaman dilakukan pada saat tanaman berumur 7 hari setelah tanam.Bibit untuk penyulaman telah disiapkan sebanyak 9 polibag.

c. Penyiangan

Penyiangan dilakukan setiap saat bila ada gulma yang tumbuh, baik di dalam polibag maupun diluar polibag. d. Pengendalian hama dan penyakit

Tanaman Terong yang terserang hama pengendaliannya menggunakan insektisida Akodan dengan konsentrasi $2 \mathrm{cc} /$ liter air. Sedangkan gangguan penyakit yang disebabkan oleh jamur dikendalikan dengan fungisida Dithane M-45 dengan dosis $2 \mathrm{~g} /$ liter air.

Panen

Tanaman Terong sudah mulai bisa dipanen umur \pm 55 hari setelah tanam. Kriteria panen buah terong layak panen adalah daging belum keras, warna buah mengkilat, ukuran tidak terlalu besar ataupun terlalu kecil.Pemanenan dilakukan sebanyak 4 kali, dengan interval panen 7-8 hari sekali.

\subsection{Pengambilan dan Pengumpulan Data}

Adapun parameter yang akan diamati dalam penelitian ini yaitu sebagai berikut :

Tinggi Tanaman $(\mathrm{cm})$

Pengukuran tinggi tanaman dilakukan mulai dari pangkal batang yang diberi tanda permanen sampai ujung titik tumbuh pada umur 15,30 hari dan 45hari setelah tanam.

Umur Saat Berbunga (hari)

Dihitung sejak mulai bibit dipindah ke dalam polibag sampai dengan munculnya bunga pertama kali.

Jumlah Buah Per Tanaman (buah)

Dihitung jumlah buah per tanaman setiap panen dan dijumlahkan sampai 4 kali panen.

Berat BuahPer Tanaman $(\mathrm{kg})$

Dengan menimbang berat buah segar per tanaman pada setiap kali panen 
dan dijumlahkan beratnya, dari panen pertama sampai panen keempat.

\subsection{Analisis Data}

Data yang diperoleh dianalisis menggunakan sidik ragam dalam Rancangan Acak Lengkap ( RAL) faktorial. Adapun model sidik ragam menurut Yitnosumarto (1993).

Apabila hasil sidik ragam berpengaruh tidak nyata (F.hitung $\leq$ F.tabel 5\%), maka tidak dilakukan uji lanjut, tetapi bila hasil sidik ragam berpengaruh nyata (F.hitung $\geq$ F.tabel $5 \%$ ) atau berpengaruhsangat nyata (F.hitung $\geq$ F.tabel 1\%), maka dilakukan uji lanjut dengan ujiBeda Nyata Terkecil (BNT) untuk membandingkan dua ratarata perlakuan. Adapun rumus umum Uji BNT disajikan sebagai berikut:

$$
\text { BNT 5\% = t-Tabel }(\alpha, \text { db.sisa }) \times \sqrt{\frac{2 \mathrm{KT} \mathrm{Galat}}{\text { r.t }}}
$$

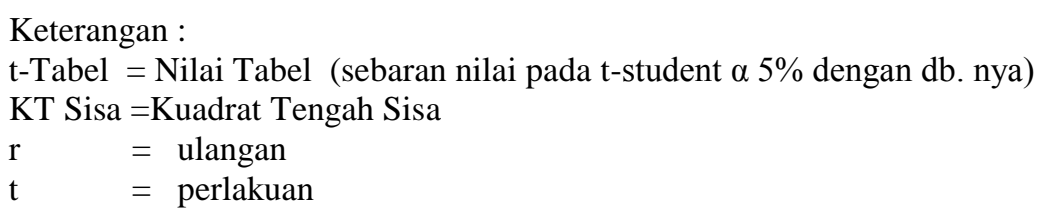

\section{HASIL PENELITIAN DAN PEMBAHASAN}

Tinggi Tanaman $(\mathrm{cm})$

1. Tinggi Tanaman Umur 15 Hari

Setelah Tanam $(\mathrm{cm})$

Hasil sidik ragam menunjukkan bahwa perlakuan jenis pupuk (K), perlakuan dosis pupuk organik (D) serta interaksinya $(\mathrm{KxD})$ tidak berpengaruh nyata terhadap tinggi tanaman umur 15 hari setelah tanam (Tabel 1).

2. Tinggi Tanaman Umur 30 Hari Setelah Tanam $(\mathrm{cm})$

Hasil sidik ragam menunjukkan bahwa perlakuan jenis pupuk (K), perlakuan dosis pupuk organik (D) serta interaksinya $(\mathrm{KxD})$ tidak berpengaruh nyata terhadap tinggi tanaman umur 30 hari setelah tanam (Tabel 1). 
Tabel 1. Rekapitulasi Data Penelitian Pengaruh Jenis dan Dosis Pupuk Organik Terhadap Pertumbuhan dan Hasil Tanaman Terong (Solanum melongena L.).

\begin{tabular}{|c|c|c|c|c|c|c|}
\hline \multirow{2}{*}{ Faktor Perlakuan } & \multicolumn{3}{|c|}{ Tinggi Tanaman (cm) } & \multirow{2}{*}{$\begin{array}{l}\text { Umur Saat } \\
\text { Berbunga } \\
\text { (hari) }\end{array}$} & \multirow{2}{*}{$\begin{array}{l}\text { Jumlah } \\
\text { Buah/ } \\
\text { Tanaman } \\
\text { (buah) }\end{array}$} & \multirow{2}{*}{$\begin{array}{l}\text { Berat } \\
\text { Buah/ } \\
\text { Tanaman } \\
(\mathrm{kg})\end{array}$} \\
\hline & $15 \mathrm{HST}$ & $30 \mathrm{HST}$ & $45 \mathrm{HST}$ & & & \\
\hline $\begin{array}{l}\text { Jenis Pupuk } \\
\text { Organik (K) } \\
\text { Sidik Ragam }\end{array}$ & $\operatorname{tn}$ & tn & $*$ & tn & $* *$ & $* *$ \\
\hline $\operatorname{Kompos}\left(\mathrm{k}_{1}\right)$ & 7,25 & 21,50 & $43,42 b$ & 36,67 & $13,67 \mathrm{~b}$ & $1,14 \mathrm{~b}$ \\
\hline Kand.Sapi $\left(\mathrm{k}_{2}\right)$ & 6,83 & 22,08 & $47,17 \mathrm{a}$ & 35,42 & $14,17 \mathrm{~b}$ & $1,18 \mathrm{~b}$ \\
\hline Kand.Ayam $\left(\mathrm{k}_{3}\right)$ & 7,08 & 22,75 & 46,67 a & 35,17 & 16,92 a & $1,62 \mathrm{a}$ \\
\hline $\begin{array}{l}\text { Dosis Pupuk } \\
\text { Organik (D) } \\
\text { Sidik Ragam }\end{array}$ & $\operatorname{tn}$ & tn & $\operatorname{tn}$ & tn & $* *$ & $* *$ \\
\hline $50 \mathrm{~g} / \tan .\left(\mathrm{d}_{1}\right)$ & 7,00 & 21,75 & 45,25 & 35,58 & $14,00 \mathrm{~b}$ & $1,18 \mathrm{c}$ \\
\hline $100 \mathrm{~g} / \tan .\left(\mathrm{d}_{2}\right)$ & 7,08 & 22,08 & 45,42 & 35,42 & $14,67 \mathrm{~b}$ & $1,31 \mathrm{~b}$ \\
\hline $150 \mathrm{~g} / \tan .\left(\mathrm{d}_{3}\right)$ & 7,08 & 22,50 & 46,58 & 35,25 & $16,17 \mathrm{a}$ & $1,46 \mathrm{a}$ \\
\hline
\end{tabular}

\begin{tabular}{|c|c|c|c|c|c|c|}
\hline $\begin{array}{c}\text { Interaksi }(\mathrm{KxD}) \\
\text { Sidik Ragam }\end{array}$ & $\operatorname{tn}$ & tn & tn & tn & $*$ & $*$ \\
\hline $\mathrm{k}_{1} \mathrm{~d}_{1}$ & 7,25 & 21,75 & 41,50 & 35,75 & $13,25 \mathrm{e}$ & $1,09 \mathrm{e}$ \\
\hline $\mathrm{k}_{1} \mathrm{~d}_{2}$ & 7,25 & 20,50 & 42,25 & 35,75 & $13,25 \mathrm{e}$ & $1,14 \mathrm{e}$ \\
\hline $\mathrm{k}_{1} \mathrm{~d}_{3}$ & 7,25 & 22,25 & 46,50 & 35,50 & 14,50 cde & $1,19 \mathrm{de}$ \\
\hline $\mathrm{k}_{2} \mathrm{~d}_{1}$ & 6,75 & 22,25 & 45,25 & 36,00 & $13,50 \mathrm{de}$ & $1,06 \mathrm{e}$ \\
\hline $\mathrm{k}_{2} \mathrm{~d}_{2}$ & 6,75 & 22,00 & 48,50 & 34,75 & $14,50 \mathrm{cde}$ & $1,17 \mathrm{e}$ \\
\hline $\mathrm{k}_{2} \mathrm{~d}_{3}$ & 7,00 & 22,00 & 47,75 & 35,50 & $14,75 \mathrm{~cd}$ & $1,32 \mathrm{~cd}$ \\
\hline $\mathrm{k}_{3} \mathrm{~d}_{1}$ & 7,00 & 21,25 & 49,00 & 35,00 & $15,25 \mathrm{bc}$ & $1,39 \mathrm{c}$ \\
\hline $\mathrm{k}_{3} \mathrm{~d}_{2}$ & 7,25 & 23,75 & 45,50 & 35,75 & $16,25 \mathrm{~b}$ & $1,61 \mathrm{~b}$ \\
\hline $\mathrm{k}_{3} \mathrm{~d}_{3}$ & 7,00 & 23,25 & 45,50 & 34,75 & $19,25 \mathrm{a}$ & $1,86 \mathrm{a}$ \\
\hline
\end{tabular}

Keterangan :

*: berpengaruh nyata

**: berpengaruh sangat nyata

tn : tidak berpengaruh nyata

HST : Hari Setelah Tanam

tan. : tanaman 


\section{Tinggi Tanaman Umur 45 Hari Setelah} Tanam $(\mathrm{cm})$

Hasil sidik ragam menunjukkan bahwa perlakuan jenis pupuk (K) berpengaruh nyata, sedangkan perlakuan dosis pupuk organik (D) dan interaksinya $(\mathrm{KxD})$ tidak berpengaruh nyata terhadap tinggi tanaman umur 45 hari setelah tanam (Tabel 1).

Hasil uji BNT taraf 5\% pada perlakuan jenis pupuk organik (K) menunjukkan bahwa perlakuan $\mathrm{k}_{3}$ dan $\mathrm{k}_{2}$ saling tidak berbeda nyata, tetapi kedua perlakuan tersebut berbeda nyata dengan perlakuan $\mathrm{k}_{1}$.

\section{Umur Saat Berbunga (hari)}

Hasil sidik ragam menunjukkan bahwa perlakuan jenis pupuk (K), perlakuan dosis pupuk organik (D) serta interaksinya $(\mathrm{KxD})$ tidak berpengaruh nyata terhadap umur saat berbunga (Tabel 1).

\section{Jumlah Buah Per Tanaman (buah)}

Hasil sidik ragam menunjukkan bahwa perlakuan jenis pupuk (K), perlakuan dosis pupuk organik (D) berpengaruh sangat nyata, sedangkan interaksinya $(\mathrm{KxD})$ berpengaruh nyata terhadap jumlah buah per tanaman (Tabel $1)$.

Hasil uji BNT taraf 5\% pada perlakuan jenis pupuk organic (K) menunjukkan bahwa perlakuan $\mathrm{k}_{3}$ berbeda nyata dengan perlakuan $\mathrm{k}_{2}$ dan $\mathrm{k}_{1}$. Perlakuan $\mathrm{k}_{2}$ dan $\mathrm{k}_{1}$ saling berbeda tidak nyata.

Hasil uji BNT taraf 5\% pada perlakuan dosis pupuk organik (D) menunjukkan bahwa perlakuan $\mathrm{d}_{3}$ berbeda nyata dengan perlakuan $\mathrm{d}_{2}$ dan $d_{1}$. Perlakuan $d_{2}$ dan $d_{1}$ saling berbeda tidak nyata.

Hasil uji BNT taraf 5\% menunjukkan bahwa interaksi perlakuan
(KxD) menunjukkan bahwa perlakuan $\mathrm{k}_{3} \mathrm{~d}_{3}$ berbeda nyata dengan perlaskuan $\mathrm{k}_{3} \mathrm{~d}_{2}, \mathrm{k}_{3} \mathrm{~d}_{1}, \mathrm{k}_{2} \mathrm{~d}_{3}, \mathrm{k}_{2} \mathrm{~d}_{2}, \mathrm{k}_{1} \mathrm{~d}_{3}, \mathrm{k}_{2} \mathrm{~d}_{1}, \mathrm{k}_{1} \mathrm{~d}_{1}$ dan $\mathrm{k}_{1} \mathrm{~d}_{2}$. Perlakuan $\mathrm{k}_{3} \mathrm{~d}_{2}$ tidak berbeda nyata dengan perlakuan $\mathrm{k}_{3} \mathrm{~d}_{1}$, tetapi berbeda nyata dengan perlakuan $\mathrm{k}_{2} \mathrm{~d}_{3}, \mathrm{k}_{2} \mathrm{~d}_{2}, \mathrm{k}_{1} \mathrm{~d}_{3}$, $\mathrm{k}_{2} \mathrm{~d}_{1}, \mathrm{k}_{1} \mathrm{~d}_{1}$ dan $\mathrm{k}_{1} \mathrm{~d}_{2}$. Perlakuan $\mathrm{k}_{3} \mathrm{~d}_{1}$ tidak berbeda nyata dengan perlakuan $\mathrm{k}_{2} \mathrm{~d}_{3}$, $\mathrm{k}_{2} \mathrm{~d}_{2}$ dan $\mathrm{k}_{1} \mathrm{~d}_{3}$, tetapi berbeda nyata dengan perlakuan $\mathrm{k}_{2} \mathrm{~d}_{1}, \mathrm{k}_{1} \mathrm{~d}_{1}$ dan $\mathrm{k}_{1} \mathrm{~d}_{2}$. Perlakuan $\mathrm{k}_{2} \mathrm{~d}_{3}$ tidak berbeda nyata dengan perlakuan $\mathrm{k}_{2} \mathrm{~d}_{2}, \mathrm{k}_{1} \mathrm{~d}_{3}, \mathrm{k}_{2} \mathrm{~d}_{1}$, tetapi berbeda nyata dengan perlakuan $\mathrm{k}_{1} \mathrm{~d}_{1}$ dan $\mathrm{k}_{1} \mathrm{~d}_{2}$. Perlakuan $\mathrm{k}_{2} \mathrm{~d}_{2}, \mathrm{k}_{1} \mathrm{~d}_{3}, \mathrm{k}_{2} \mathrm{~d}_{1}, \mathrm{k}_{1} \mathrm{~d}_{1}$ dan $\mathrm{k}_{1} \mathrm{~d}_{2}$ satu sama lainnya saling berbeda tidak nyata.

Berat Buah Per Tanaman (kg)

Hasil sidik ragam menunjukkan bahwa perlakuan jenis pupuk (K), perlakuan dosis pupuk organik (D) berpengaruh sangat nyata, sedangkan interaksinya $(\mathrm{KxD})$ berpengaruh nyata terhadap berat buah per tanaman (Tabel 1)

Hasil uji BNT taraf 5\% pada perlakuan jenis pupuk organik (K) menunjukkan bahwa perlakuan $\mathrm{k}_{3}$ berbeda nyata dengan perlakuan $\mathrm{k}_{2}$ dan $\mathrm{k}_{1}$. Perlakuan $\mathrm{k}_{2}$ dan $\mathrm{k}_{1}$ saling berbeda tidak nyata.

Hasil uji BNT taraf 5\% pada perlakuan dosis pupuk organik (D) menunjukkan bahwa perlakuan $\mathrm{d}_{3}, \mathrm{~d}_{2}$ dan $\mathrm{d}_{1}$ satu sama lainnya saling berbeda nyata.

Hasil uji BNT taraf 5\% menunjukkan bahwa interaksi perlakuan (KxD) menunjukkan bahwa perlakuan $\mathrm{k}_{3} \mathrm{~d}_{3}$ berbeda nyata dengan perlakuan $\mathrm{k}_{3} \mathrm{~d}_{2}, \mathrm{k}_{3} \mathrm{~d}_{1}, \mathrm{k}_{2} \mathrm{~d}_{3}, \mathrm{k}_{1} \mathrm{~d}_{3}, \mathrm{k}_{2} \mathrm{~d}_{2}, \mathrm{k}_{1} \mathrm{~d}_{2}, \mathrm{k}_{1} \mathrm{~d}_{1}$ dan $\mathrm{k}_{2} \mathrm{~d}_{1}$. Perlakuan $\mathrm{k}_{3} \mathrm{~d}_{2}$ tidak berbeda nyata dengan perlakuan $\mathrm{k}_{3} \mathrm{~d}_{1}$, tetapi berbeda nyata dengan perlakuan $\mathrm{k}_{2} \mathrm{~d}_{3}, \mathrm{k}_{1} \mathrm{~d}_{3}, \mathrm{k}_{2} \mathrm{~d}_{2}$, $\mathrm{k}_{1} \mathrm{~d}_{2}, \mathrm{k}_{1} \mathrm{~d}_{1}$ dan $\mathrm{k}_{2} \mathrm{~d}_{1}$. Perlakuan $\mathrm{k}_{3} \mathrm{~d}_{1}$ tidak berbeda nyata dengan perlakuan $\mathrm{k}_{2} \mathrm{~d}_{3}$, $\mathrm{k}_{1} \mathrm{~d}_{3}, \mathrm{k}_{2} \mathrm{~d}_{2}$, tetapi berbeda nyata dengan 
perlakuan $\mathrm{k}_{1} \mathrm{~d}_{2}, \mathrm{k}_{1} \mathrm{~d}_{1}$ dan $\mathrm{k}_{2} \mathrm{~d}_{1}$.Perlakuan , $\mathrm{k}_{2} \mathrm{~d}_{3}$ tidak berbeda nyata dengan perlakuan $\mathrm{k}_{1} \mathrm{~d}_{3}, \mathrm{k}_{2} \mathrm{~d}_{2}$ dan $\mathrm{k}_{1} \mathrm{~d}_{2}$, tetapi berbeda nyata dengan perlakuan $\mathrm{k}_{1} \mathrm{~d}_{1}$ dan $\mathrm{k}_{2} \mathrm{~d}_{1}$. Perlakuan $\mathrm{k}_{1} \mathrm{~d}_{3}, \mathrm{k}_{2} \mathrm{~d}_{2}, \mathrm{k}_{1} \mathrm{~d}_{2}, \mathrm{k}_{1} \mathrm{~d}_{1}$ dan $\mathrm{k}_{2} \mathrm{~d}_{1}$ satu sama lainnya saling berbeda tidak nyata.

Pengaruh Jenis Pupuk Organik Terhadap Pertumbuhan dan Hasil Tanaman Terong (Solanum melongena L). Hasil sidik ragam menunjukkan bahwa perlakuan jenis pupuk organik tidak berpengaruh nyata terhadap tinggi tanaman umur 15 dan 30 hari setelah tanam, dan umur saat berbunga. Berpengaruh nyata terhadap tinggi tanaman umur 45 hari setelah tanam, Berpengaruh sangat nyata terhadap jumlah buah per tanaman dan berat buah per tanaman.

Perlakuan jenis pupuk organik tidak berpengaruh nyata pada tinggi tanaman terung umur 15 hari dan 30 hari setelah tanam, baik pupuk kompos, pupuk kandang sapi maupun pupuk kandang ayam, hal ini diduga bahwa pupuk organik tersebut belum sepenuhnya bisa diserap oleh akar tanaman, karena berdasarkan hasil analisis tanah di media polibag sebelum penanaman, pH-nya tergolong asam ( $\mathrm{pH} \mathrm{5,42),} \mathrm{C-organik}$ rendah $(1,13 \%), \mathrm{C} / \mathrm{N}$-rasio sedang (14), $\mathrm{N}$-total sangat rendah $(0,08 \%)$, $\mathrm{P}$ tersedia sangat rendah $(2,9 \mathrm{ppm})$, dan $\mathrm{K}$ tersedia sedang (28 ppm).Keadaan $\mathrm{pH}-$ tanah pada media tanam bisa berpengaruh terhadap proses peruaraian (mineralisasi) bahan organik, baik langsung maupun tidak langsung terhadap pertumbuhan tanaman. Menurut Hardjowigeno (2010) bahwa keadaan $\mathrm{pH}$-tanah berpengaruh terhadap ketersediaan unsur hara, terutama kelarutan unsur $\mathrm{Al}$ dan Fe. Pada $\mathrm{pH}$ asam kelarutan beberapa unsur hara menurun, dan kelarutan $\mathrm{Al}$ dan $\mathrm{Fe}$ meningkat, sehingga bila diserap oleh akar tanaman bisa menyebabkan keracunan, dan bisa menyebabkan tanaman kerdil atau mati. Walaupun pupuk organik diberikan pada media tanam, dengan maksud untuk meningkatkan bahan organik di dalam tanah, yang berperan untuk menambah ketersediaan unsur hara, memperbaiki sifat fisik dan biologi tanah, namun belum berpengaruh nyata pada parameter tinggi tanaman umur 15hari dan 30 hari setelah tanam, hal ini disebabkan pupuk organik yang diberikan memerlukan waktu yang cukup lama agar bereaksi sempurna dengan kondisi $\mathrm{pH}$-tanah yang rendah di medi tanam. Menurut Hardjowigeno (2010), pemberian pupuk organik pada beberapa tanah asam dapat menaikkan pH-tanah, dan juga dapat meningkatkan ketersediaan unsur hara makro mapun mikro, walaupun dalam jumlah relatif sedikit.

Pada parameter tinggi tanaman umur 45 hari setelah tanam, pemberian jenis pupuk organik berpengaruh nyata, hal ini diduga bahwa pupuk organik yang diberikan sudah bereaksi dengan $\mathrm{pH}$ tanah di media tanam, dan kemungkinan pH-tanah sudah meningkat, sehingga unsur hara mudah diserap oleh akar tanaman, sehingga meningkatkan pertumbuhan tinggi tanaman.

Pada fase pertumbuhan generatif, terutama jumlah buah dan berat buah tanaman terung, perlakuan jenis pupuk organik berpengaruh sangat nyata. Jumlah buah terbanyak dan berat buah terberat per tanaman terdapat pada perlakuan jenis pupuk kandang ayam $\left(\mathrm{k}_{3}\right)$, yaitu 16,92 buah, dan 1,62 kg/tanaman. Sedangkan jumlah buah paling sedikit dan berat buah terringan terdapat pada perlakuan pupuk kompos $\left(\mathrm{k}_{1}\right)$, yaitu 13,67 buah, dan 1,14 $\mathrm{kg} / \mathrm{tanaman}$. Pengaruh jenis pupuk kandang ayam menunjukkan hasil yang lebih baik dibandingkan dengan jenis pupuk kompos dan pupuk kandang sapi, hal ini disebabkan bahwa pupuk kandang 
ayam memiliki jumlah unsur hara yang lebih banyak dibandingkan jenis pupuk kandang lainnya. Hal ini sesuai dengan pendapat Hardjowigeno (2010), bahwa pupuk kandang ayam mengandung unsur hara tiga kali lebih besar dibandingkan pupuk kandang lainnya. Kandungan unsur pada pupuk kandang ayam, terutama unsur hara makro sebagaimana dikemukakan oleh Musnamar (2009), kandungan unsur $\mathrm{N}_{2}(1,00-3,13)$, $\mathrm{P}_{2} 0_{5}(2,80-6,00)$, dan $\mathrm{K}_{2} \mathrm{O}(0,40-2,90)$, sedangakan pupuk kandang sapi mengandung $\mathrm{N}_{2}\left(0,10-0,96, \mathrm{P}_{2} \mathrm{O}_{5}(0,64-\right.$ $1,15)$, dan $\mathrm{K}_{2} \mathrm{O}(0,45-1,00)$ dan kandungan unsur hara pada pupuk kompos alami, yaitu unsur $\mathrm{N}_{2}(0,10-$ $0,51), \mathrm{P}_{2} 0_{5}(0,35-1,12)$, dan $\mathrm{K}_{2} 0(0,32-$ $0,80)$.Selanjutnya menurut Musnamar (2009), pupuk kandang ayam mengandung unsur hara lengkap yang dibutuhkan oleh tanaman untuk pertumbuhan dan perkembangan tanaman seperti unsur nitrogen $(\mathrm{N})$, fosfor $(\mathrm{P})$, kalium (K), kalsium (Ca), magnesium $(\mathrm{Mg})$ dan sulfur (S). Unsur $\mathrm{N}$ yang diserap tanaman merupakan bahan penyusun asam amino dan sebagai dasar penyusun senyawa protein, lemak dan protein bersama dengan unsur $\mathrm{P}$ dan $\mathrm{K}$, untuk meningkatkan pertumbuhan vegetatif dan generatif tanaman (Winarso, 2005).

Karena mengandung unsurhara yang lebih banyak, maka pupuk kandang ayam menyumbangkan unsur hara yang lebih banyak pula, sehingga tanaman mampu menyerap unsur hara lebih banyak untuk pertumbuhannya. Karena perlakuan pupuk kandang ayam menghasilkan jumlah buah per tanaman terbanyak, maka pada parameter berat buah per tanaman menghasilkan berat buah per tanaman tertinggi pula.

Pengaruh Dosis Pupuk Organik Terhadap Pertumbuhan dan Hasil Tanaman Terong (Solanum melongena L.). Hasil sidik ragam menunjukkan bahwa perlakuan dosis pupuk organik tidak berpengaruh nyata terhadap tingi tanaman umur 15, 30 dan 45 hari setelah tanam, dan umur saat berbunga. Berpengaruh sangat nyata terhadap jumlah buah per tanaman dan berat buah per tanaman.

Perlakuan dosis pupuk organik tidak memberikan pengaruh yang nyata terhadap tinggi tanaman umur 15 hari, 30 hari dan 45 hari setelah tanam dan umur saat berbunga, hal ini diduga erat kaitannya dengan kondisi $\mathrm{pH}$-tanah di media tanam. Berdasarkan hasil analisis tanah penelitian di laboratorium dan kriteria kesuburan tanah, $\mathrm{pH}$-tanahnya tergolong asam ( $\mathrm{pH}$ 5,42), keadaan seperti ini sangat berpengaruh terhadap ketersediaan unsur hara bagi pertumbuhan dan perkembangan tanaman (Winarso, 2005). Karena ketersediaan unsur hara berkurang, maka unsur hara yang diserap tanaman juga terbatas, sehingga pertumbuhan tanaman juga belum menunjukkan hasil yang signifikan.

Perlakuan dosis pupuk organik berpengaruh sangat nyata terhadap parameter jumlah buah dan berat buah per tanaman, hal ini disebabkan dengan dewasanya pertumbuhan dan perkembangan tanaman, maka proses perombakan pupuk organik menjadi unsur hara (bahan mineral) berjalan dengan baik, sehingga tersedia unsur hara bagi keperluan pertumbuhan tanaman. Sebagimana dikemukakan oleh Hakim dkk. (1986), bahwa penambahan pupuk kandang kedalam tanah selain meningkatkan jumlah danaktivitas mikroorganisme tanah, juga dapatmenyediakan unsur hara bagi tanaman,mempertinggi humus, memperbaiki strukturtanah dan memiliki daya jerap kation yanglebih besar daripada koloid liat sehingga dapatmeningkatkan nilai kapasitas tukar kation (KTK).Terdapat kecenderungan 
dengan semakin meningkatnya pupuk organik, yaitu dari dosis pupuk 50 $\mathrm{g} /$ tanaman, $100 \mathrm{~g} /$ tanaman dan 150 gram per tanaman yang diberikan, maka jumlah buah dan berat buah terung semakin meningkat pula. Jumlah buah terbanyak dan berat buah terberat terdapat pada perlakuan dosis pupuk organik 150 g/tanaman, yaitu 16,17 buah/tanaman dan $1,46 \mathrm{~kg} /$ tanaman, sedangkan yang terendah terdapat pada perlakuan dosis pupuk 50 g/tanaman, yaitu 14 buah/tanaman dan 1,18 kg/tanaman. Semakin meningkat jumlah pupuk yang diberikan berarti semakin banyak tersedia unsur hara bagi pertumbuhan tanaman, terutama peran unsur hara makro seperti N, P, K. Menurut Lingga (1995), unsur N berperan dalam merangsang pertumbuhan tanaman seperti batang, daun dan pembentukan hujau daun yang berperan dalam proses fotosintesis sebagai bahan pembentuk protein. Unsur $P$ mempercepat proses pembungaan dan pembuahan serta pemasakan buah, unsur $\mathrm{K}$ membantu pembentukan protein dan karbohidrat (Marsono dan Sigit, 2008).Dengan demikian maka semakin banyak terbentuk buah dan meningkatkan berat buah secara keseluruhan. Hasil Penelitian analisa tanah di Desa Giri Agung KTK kebanyakan rendah, dan masam adapun KTK yang rendah dapat ditingkatkan dengan penggunaan pupuk organik yang berguna untuk meningkatkan tanah menjadi gembur dan daya jerap tanah dan untuk meningkatkan kapasitas tukar kation sehingga dapat menampung apabila dilakukan penambahan unsur hara baik secara alami maupun dengan penambahan pupuk (Datu., et al. 2013). Selanjutnya pemupukan ditentukan oleh keadaan tanah seperti Tanah-tanah pada lokasi studi menunjukkan reaksi tanah agak masam perlu dilakukan pemberian kapur (I Gede., et al. 2017).
Pengaruh Interaksi Perlakuan Jenis dan Dosis Pupuk Organik Terhadap Pertumbuhan dan Hasil Tanaman Terong (Solanum melongena L.). Hasil sidik ragam menunjukkan bahwa interaksi perlakuan tidak berpengaruh nyata terhadap tinggi tanaman umur 15, 30 dan 45 hari setelah tanam, dan umur saat berbunga. Berpengaruh nyata terhadap jumlah buah per tanaman dan berat buah per tanaman.

Perlakuan interaksi antara jenis dan dosis pupuk organik berdasarkan analsis sidik ragam berpengaruh nyata pada parameter jumlah buah per tanaman dan berat buah per tanaman. Jumlah buah terbanyak dan berat buah terberat terdapat pada perlakuan $\mathrm{k}_{3} \mathrm{~d}_{3}$ (pupuk kandang ayam dengan dosis 150 g/tanaman), yaitu 19,25 buah dan 1,86 $\mathrm{kg} /$ tanaman, sedangkan yang terendah terdapat pada perlakuan $\mathrm{k}_{1} \mathrm{~d}_{1}$ (pupuk kompos dengan dosis $50 \mathrm{~g} /$ tanaman), yaitu 13,25 buah dan 1,09 kg/tanaman. Hal ini disebabkan bahwa pupuk kandang ayam memiliki jumlah unsur hara yang lebih banyak dibandingkan dengan pupuk kompos dan pupuk kandang sapi, sehingga dengan semakin meningkat jumlah pupuk yang diberikan, maka akan semakin banyak unsur hara yang tersedia bagi tanaman untuk pertumbuhan vegetatif dan generatif, terutama dalam pembentukan jumlah buah dan berat buah tanaman. Sebagimana dikemukan oleh Musnamar (2009) bahwa kandungan unsur hara pada pupuk kandang ayamtiga kali lebih besar dari pupuk kandang lainnya.

\section{KESIMPULAN}

Kesimpulan dari hasil penelitian adalah sebagai berikut: Perlakuan jenis pupuk organik (K) tidak berpengaruh nyata terhadap tinggi tanaman umur 15 dan 30 hari setelah tanam, dan umur saat berbunga. Berpengaruh nyata terhadap 
tinggi tanaman umur 45 hari setelah tanam, Berpengaruh sangat nyata terhadap jumlah buah per tanaman dan berat buah per tanaman. Berat buah terung tertinggi terdapat pada perlakuan $\mathrm{k}_{3}$ (pupuk kandang ayam), yaitu 1,62 $\mathrm{kg} /$ tanaman, sedangkan yang terendah terdapat pada perlakuan $\mathrm{k}_{1}$ (pupuk kompos), yaitu $1,14 \mathrm{~kg} /$ tanaman.

Perlakuan dosis pupuk organik (D) tidak berpengaruh nyata terhadap tingi tanaman umur 15, 30 dan 45 hari setelah tanam, dan umur saat berbunga. Berpengaruh sangat nyata terhadap jumlah buah per tanaman dan berat buah per tanaman. Berat buah terong tertinggi terdapat pada perlakuan $\mathrm{d}_{3}$ (pupuk kandang ayam), yaitu 1,46 kg/tanaman, sedangkan yang terendah terdapat pada perlakuan $\mathrm{d}_{1}$ (pupuk kompos), yaitu 1,18 $\mathrm{kg} /$ tanaman

Interaksi perlakuan (KxD) tidak berpengaruh nyata terhadap tinggi tanaman umur 15, 30 dan 45 hari setelah tanam, dan umur saat berbunga. Berpengaruh nyata terhadap jumlah buah per tanaman dan berat buah per tanaman. Berat buah terong tertinggi terdapat pada perlakuan $\mathrm{k}_{3} \mathrm{~d}_{3}$ (pupuk kandang ayam dengan dosis $150 \mathrm{~g} /$ tanaman), yaitu 1,46 $\mathrm{kg} /$ tanaman, sedangkan yang terendah terdapat pada perlakuan $\mathrm{k}_{1} \mathrm{~d}_{1}$ (pupuk kompos dengan dosis $50 \mathrm{~g} /$ tanaman), yaitu $1,09 \mathrm{~kg} / \mathrm{tanaman}$.

\section{DAFTAR PUSTAKA}

Biro Pusat Statistik. (2015). Kaliamantan Timur Dalam Angka. Samarinda.

EB, I. G., \& Jumani. (2017). Evaluation of Soil Revegetation Success Rate Ex-Pit Coal Mine in Kitadin site Embalut Kutai in East Kalimantan. Agrifor, 16(2), 195-208.

Hakim, N., Nyakpa, M.Y., Lubis, A,M., Nugroho, S.T., Saul, M.R., Diha, M.A., Hong, G.B., dan Bailey. H.H. (1986). Dasar-Dasar Ilmu Tanah. Lampung: Penerbit Universitas Lampung.

Hardjowigeno, S. (2010). Ilmu Tanah. Jakarta: Akademika Pressindo.

Lingga, P.,dan Marsono. (2009). Petunjuk Pengunaan Pupuk. Jakarta: Penebar Swadaya.

Lingga, P. (1995). Petunjuk Penggunaan Pupuk. Jakarta: Penebar Swadaya.

Marsono dan Sigit, P. (2008). Pupuk Akar, Jenis dan Aplikasi. Jakarta: Penebar Sawdaya. 
Musnamar, A. (2009). Kesuburan Tanah dan Nutrisi Tanaman. Bogor: IPB Press.

Pramana, D. B. (2013). Pertumbuhan Tanaman Gaharu (Aquilaria sp.) di Desa Giri Agung Kecamatan Sebulu Kabupaten Kutai Kartanegara Provinsi Kalimantan Timur. Agrifor, 11(2), 110-114.

Rukmana.(1994). Budidaya Terong. Yogyakarta: Kanisius.
Winarso, S. (2005). Kesuburan Tanah, Dasar Kesehatan dan Kualitas Tanah. Yogyakarta: Gaya Media.

Yitnosumarto, S. (1993). Percobaan, Perancangan, Analisis dan Interpretasinya. Jakarta: Gramedia. 